\title{
An International History of Terrorism: Western and Non-Western Experiences. Edited by Jussi M. Hanhimaki and Bernhard Blumenau. London, New York, and Canada, Routledge, Taylor and Francis Group, 2013.
}

Millard E. Moon Ed.D., Colonel (ret.)

U.S. Air Force Office of Special Investigations

Follow this and additional works at: https://digitalcommons.usf.edu/jss pp. $120-121$

\section{Recommended Citation}

Moon, Millard E. Ed.D., Colonel (ret.). "An International History of

Terrorism: Western and Non-Western Experiences. Edited by Jussi M. Hanhimaki and Bernhard Blumenau. London, New York, and Canada, Routledge, Taylor and Francis Group, 2013.." Journal of Strategic Security 6, no. 3 (2013) : 120-121.

DOI: http://dx.doi.org/10.5038/1944-0472.6.3.10

Available at: https://digitalcommons.usf.edu/jss/vol6/iss3/10

This Book Review is brought to you for free and open access by the Open Access Journals at Digital Commons @ University of South Florida. It has been accepted for inclusion in Journal of Strategic Security by an authorized editor of Digital Commons @ University of South Florida. For more information, please contact digitalcommons@usf.edu. 


\section{An International History of Terrorism: Western and Non- Western Experiences. Edited by Jussi M. Hanhimaki and Bernhard Blumenau. London, New York, and Canada, Routledge, Taylor and Francis Group, 2013.}




\section{An International History of Terrorism: Western and Non-Western Experiences. Edited by Jussi M. Hanhimaki and Bernhard Blumenau. London, New York, and Canada, Routledge, Taylor and Francis Group, 2013. ISBN: 978-0-41563540-0 (hardback), ISBN: 978-0-415-63541-7 (paperback) ISBN: 978-0-203-09346-7 (e-book), Notes. Index. Pp 318. Softcover: $\$ 47.95$}

The editors have compiled sixteen essays which were presented at a two-day conference on "Terrorism and International Politics: Past, Present, and Future" held in September 2011, at the Graduate Institute of International and Development Studies in Geneva. This conference was sponsored by the Pierre du Bois Foundation for Current History. All essays are academic works with supporting notes following each paper. In the introduction there is, among other points, a discussion of the definition of terrorism. Like the statement by a U.S. Supreme Court Justice who said that he knew porn when he saw it, most people probably think they know terrorism when they see it. These editors point out the difficulties in obtaining a widely accepted definition of terrorism to fit world-wide situations. As others have observed, one side's terrorist today may be the opposite side's national hero tomorrow.

Hanhimaki and Blumenau have organized the essays into four major groups, Terrorism prior to the Cold War, Western experiences with terrorism, Non-Western experiences with terrorism, Contemporary terrorism and anti-terrorism, and in Part Five a concluding essay by David C. Rapoport actually summarizes the history of terrorism in a way that provides a nice complement to the other fifteen essays in the collection.

Part I, Terrorism prior to the Cold War, is comprised of three essays. In order, the papers discuss the first global wave of terrorism identified as the period of 1905-1914, and international counterterrorism responses. Next is an essay dealing with international responses highlighting problems in the international community including a workable extradition process which can obviously remain a problem on the stage of international relations. The somewhat ineffectual actions by the League of Nations are also addressed. The last paper in this section addresses actions taken in Spain to combat terrorist activities from the late 1800s into the 1920s. Unfortunately, it is obvious there have always been difficulties in separating the interests of individual nations in the international political world from the requirements for a unified world policy against terrorism.

In Part II, Western experiences with terrorism, there are five essays. The first three discuss specific problems in West Germany and the support of United Nations efforts in the 1970s, Leftist political violence in France during the years of 1968-1974, and the success of Italy's counterterrorism efforts in the years 1969 to 1982, when sympathizers could be given amnesty and terrorists could receive reduced sentences based on cooperation with government forces in combating terror groups. A fourth paper addresses state sponsorship of terrorism in the Cold War. The major emphasis is on the actions of Eastern block and Middle-East countries actively supporting terror for political gains against the West. The fifth essay is an analysis of the hijacking of TWA-847. This study challenges some of the conventional ideas about the entire incident which resulted in the brutal murder of U.S. Navy diver Robert Stetham. 
Part III, Non-Western experiences with terrorism contains four papers. The first discusses Bengal terrorism and the ambiguity of Bengali Muslims. Next is an essay on the South West Africa People's Organization (SWAPO), the United Nations, and the fight for liberation and a new nation. The third essay is on the "Claustre Affair," dealing with a hostage crisis, the French government, and a civil war in Chad during 1974-1977. The final paper discusses United States policy under President Reagan and his administration's attempt to encourage a regime change in Libya. The concept of pre-emptive strikes against state-sponsored terrorism is a focal point. The author points out the use of force attempt at regime change failed.

Part IV, Contemporary terrorism and anti-terrorism contains three essays. First, Al Qaeda, the reinvention of terrorism, and the challenge of transnational political violence are examined. The U.S. response to contemporary terrorism is the topic of the second essay. The final paper in this group looks at terrorism as a new era of warfare.

In Part V, Concluding essay, David C. Rapoport's well organized paper addresses four waves of terrorism. In describing the "wave phenomenon" Rapoport defines a wave as "a cycle of activity in a given time period with expansion and contraction phases" (p. 283). He identifies the "Anarchist Wave" as the first terrorist movement with global activity, then discusses the "AntiColonial Wave," the "New Left Wave," and finally the "Religious Wave." His discussions of each period can help in understanding the motivations of the groups that give rise to, and perpetuate, terrorist activity.

Obviously these essays are well researched and documented in accepted academic style. The views of the writers may sometimes be from a different perspective that that of an average observer in the United States. Even though some may disagree with some certain conclusions, a review of the material will be beneficial. Developing a reasoned argument in response to another's views can improve the foundations of one's own views. While at first glance this collection may seem best suited for academic researchers or professionals in the analytical field, there are good basic lessons for those oriented toward practical applications. Understanding the terrorist enemy is definitely the key to ultimately defeating that enemy.

Millard E. Moon, Ed.D., Colonel (ret), U.S. Air Force Office of Special Investigations 